Article

\title{
Theories of the Origin of the Samaritans-Then and Now
}

\author{
Magnar Kartveit
}

School of Mission and Theology, VID Specialized University, 4024 Stavanger, Norway; magnar.kartveit@lyse.net

Received: 17 October 2019; Accepted: 25 November 2019; Published: 4 December 2019

\begin{abstract}
The article describes the different models for understanding the origin of the Samaritans: the Samaritans' own view; Flavius Josephus' two stories; a model based upon the results of the excavations of the cities of Samaria and Shechem, plus information from ancient authors; new insights from the Dead Sea Scrolls; and models based on the results of the Mount Gerizim excavations; and the Delos inscriptions. Each of these models has its modern followers in scholarship, and their various adherents are named. A last part of the article is devoted to the state of the question of the origin of the Samaritans. The presentation is organized according to the sources because the material at hand has produced different solutions to the pertinent questions. Through quoting the texts and presenting the results of the excavations, the author gives the reader an opportunity to form her or his own opinions, both on the different theories and on the origin of the Samaritans.
\end{abstract}

Keywords: Samaritans; Samaritan origin; Mount Gerizim; Delos; Samaria; Shechem; Josephus; Dead Sea Scrolls; parable of The Good Samaritan

\section{Introduction}

A search on the internet for "Samaritans" will lead to an organization in Great Britain and Ireland-a 24/7 telephone service for people in distress-notably those with suicidal tendencies. A different search, this time for "Samaritan's Purse" will direct us to a U.S. relief organization providing food, medicare etc. in situations of need around the world. A third search will result in information on a religious group living in Israel and the West Bank today: the Samaritans. What is the connection between these three entities?

The Samaritans in Israel and the West Bank trace their history to biblical times, to the beginning of the people of Israel. Bible readers will be familiar with the parable of the "good Samaritan" in Luke 10:25-37, where Jesus tells of the stranger from northern Israel who provided medical and financial support to a traveler from Jerusalem who had fallen victim to robbers. Jesus' parable portrays a person from the Samaritan community as the model of a "neighbour", in contradistinction to the standard Jewish definition of a "neighbour". The latter definition built on the understanding of fellowship inside the religious community; Jesus brings in a person from outside that community to perform the duties of a "neighbour". This parable has provided the name to the two modern organizations, one specializing in telephone support for the existentially challenged, the other catering to physical and spiritual needs on a global basis. The parable also has given the name to numerous other charities, hospitals, welfare systems and more, around the globe. Its success has been formidable.

The New Testament mentions the Samaritans in other texts as well, notably in the narrative of Jesus' meeting with the Samaritan woman at Jacob's well in John 4 . They have a theological discussion, particularly about the correct place of worship, Jerusalem or "this mountain", which evidently is Mount Gerizim just above the valley with Jacob's well. Luke also tells about the thankful Samaritan whom Jesus healed from skin disease and who returned to thank him for the healing, Luke 17:11-19. 
Acts 8:4-25 find the apostles Philip, Peter and John preaching the gospel and healing people in Samaria. This mission is just as successful as that of Jesus in John 4.

However, there are also dissonances in this symphony of good Samaritans and Christians. Described in Acts 8, a certain Simon wants to buy the gift of the Holy Spirit, a wish fiercely rejected by Peter. Discussed in later Church texts, Simon became the originator of all gnostic and other heresies (for early Christian texts on the Samaritans see (Pummer 2002)). When Jesus sends the disciples to exorcise evil spirits and heal diseases, he emphatically tells them not to enter gentile or Samaritan villages, cf. Matthew 10:5. Jews call Jesus a "Samaritan and having a demon" in John 8:48. Luke mentions an incident where Jesus and his disciples were denied lodgings on the way to Jerusalem, 9:51-56. This diverse situation has been understood to mean that the milieu of Matthew was against the Samaritans, John's community was positive, and Luke plus Acts had a balanced approach to them. We note that the New Testament simply refers to the Samaritans, and their origin was not the concern of those authors.

One would, logically, turn to the Hebrew Bible/Old Testament for answers on this question, and the only place where the word "Samaritans" occurs, is 2 Kings 17:29. "Samaritans" was the translation of

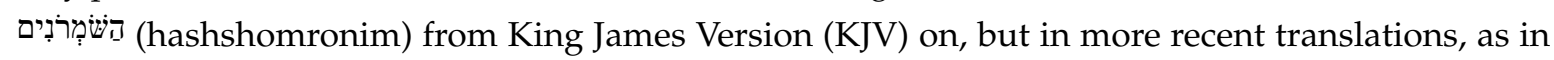
the New Revised Standard Version (NRSV), the rendering is "people of Samaria". This change in translation reflects the tendency to find the inhabitants of the area behind the Hebrew word, not the Samaritans of the New Testament or today's group. The change also is due to scholars' suggestions that it is necessary to distinguish between the religious group of the Samaritans and the inhabitants of the area Samaria.

Hence, when did the Samaritans originate? When can we speak of such a group? The research on this question has been reviewed by Reinhard Pummer, James Purvis, Ferdinand Dexinger, Ingrid Hjelm, and Magnar Kartveit (Pummer 1976, 1977, 1992, 2016; Purvis 1986; Dexinger 1992; Hjelm 2000; Kartveit 2009). Additionally, most scholarly contributions contain a chapter with research history. The overview in the following is organized according to the relevant literary, epigraphic, and archaeological material. The aim of this paper is to review opinions on the question of the origin of the Samaritans, not to discuss the origin of the Samaritans. The latter topic would require a different approach.

\section{The Samaritan Version}

The intuitive approach would be to ask the Samaritans themselves about their origin. They have a story about this, so why not start there? Such is the answer in The Kitab al-Tarikh by Abu'l Fath from 1355:

A terrible civil war broke out between Eli son of Yafnī, of the line of Ithamar, and the sons of Phinehas, because Eli son of Yafnī resolved to usurp the High Priesthood from the descendants of Phinehas. He used to offer sacrifice on the altar of stones. He was 50 years old, endowed with wealth and in charge of the treasury of the children of Israel. He continued for a time gathering a group around him to whom he said, "I am one to whom it is anathema to serve a child. I do not wish (to do) this myself, and I hope that you will not consent to it." They answered as a group and said, "We are at your command, and under your obedience: order us as you see fit, and we will not disobey." Accordingly, he made them swear that they would follow him in all his purposes. He offered a sacrifice on the altar, but without salt, as if he were inattentive. When the Great High Priest Ozzi learned of this, and found that the sacrifice was not accepted, he thoroughly disowned him; and it is (even) said that he rebuked him. Thereupon he and the group that sympathized with him, rose in revolt and at once he and his followers and his beasts set off for Shiloh. Thus Israel was split into factions. He sent to their leaders saying to them, "Anyone who would like to see wonderful things, let him come to me." Then he assembled a large group around him in Shiloh and built a Temple for himself there; he constructed for himself a place like the Temple. He built an altar, omitting no detail-it all corresponded to the original, piece by piece. Then, he had two sons, Hophni and Phinehas, who rounded up young women of attractive appearance and brought them into the Tabernacle which had been built by their father. 
They let them savour the food of the sacrifices and had intercourse with them inside the Tabernacle. Then, the children of Israel became three factions: A (loyal) faction on Mount Gerizim; an heretical faction that followed false gods; and the faction that followed Eli son of Yafnī in Shiloh. (Stenhouse 1985, pp. 47-48)

According to this story, the Samaritans constitute the original Israel, and the Jews represent the faction of Eli, priest in Shiloh. We recognize this Eli and his sons from 1 Sam 1-3, so the Samaritan story evidently builds upon this Biblical text. Additionally, it builds upon a story of the origin of the Samaritans from the nineties CE, which we find in chapter 11 of the Antiquities by Josephus (quoted below). The description in Abu'1 Fath's work is, therefore, fictional; it is an apologetic and polemical version of the circumstances leading to the two religious communities. Nevertheless, it is repeated in the Arabic Book of Joshua from 1362, and in the New Chronicle/Chronicle Adler from 1899-1900, both of them Samaritan manuscripts. Found in the Samaritan museum on the top of Mount Gerizim, this version of the origin is presented today. Additionally, this self-understanding probably is seen in the Delos inscriptions from the second century BCE, where they call themselves "Israelites" (see below). There may be, of course, some tradition behind these descriptions, even if it may be difficult to trace. The main idea in the Samaritan chronicles is that the Samaritans are Israelites, not an off-spring of Judaism. It is the way the Samaritans see the origin, up to this day, and there are scholars who follow in their footsteps (Gaster 1925; Macdonald 1964).

\section{Flavius Josephus on the Origin of the Samaritans}

Josephus has two main explanations for the origin of the Samaritans, both found in the large work Antiquities (Pummer 2009). The first we read in chapter 9:

Now those who were settled in Samareia were the "Chouthaioi" [Xov $\theta \alpha$ iol], for they are called by this name until today because they were brought in from the country called "Chouthas"; this is Persia, where there is a river that has this name. Each of the nations - there were five of them-brought its own god to Samareia. By adoring these, as was their ancestral [custom], they aroused the greatest God to wrath and rage. For he inflicted them with a plague, by which they were afflicted. Ascertaining no cure for their calamities, they learned by way of an oracle that, if they worshiped the greatest God, this would be [a source of] safety to them. They therefore dispatched messengers to the king of the Assyrians and begged him to send them priests from those he had taken captive when he warred against the Israelites. Upon his sending these and their being taught the ordinances and reverence for this God, they worshiped him lavishly and the plague immediately ceased. Even now the name "Chouthaioi" continues to be used for these nations in the Hebrew language, whereas in Greek they are called "Samareitai" [ $\Sigma \alpha \mu \alpha \rho \varepsilon \tilde{\imath} \tau \alpha \iota]$. Whenever, by turns, they see things going well for the Judeans, they call themselves their relatives, in that they are descendants of Josep [Joseph] and have family ties with them in virtue of that origin. When, however, they see that things are going badly for them [the Judeans], they say that they owe nothing to them and that they have no claim to their loyalty or race. Instead, they make themselves out to be migrants of another nation [ $\dot{\alpha} \lambda \lambda \mathrm{\alpha} \varepsilon \theta v \varepsilon \tilde{\imath} \varsigma]$. But about these matters we shall have to speak in a more suitable place (Ant. 9.288-291; Begg and Spilsbury 2005).

The dependence on 2 Kings $17^{1}$ is evident, and Josephus here explains the origin of the people in Samaria after 721 BCE. They descend from the five peoples imported by the Assyrian king Salmanasser (Ant. 9.277-278). Through singling out one of the names in 2 Kings 17, Kuthean/Choutaioi, he laid the ground for the rabbinic name for the Samaritans. The story, therefore, also becomes an origin story for the Samaritans. He does not state, however, that the Samaritans were a mixed population from imported expatriates and original inhabitants, nor that they were syncretists. Syncretism may be assumed on the basis of this text and of 2 Kings 17:33, but it is not expressed. The idea of a mixed

12 Kings 17 is a composite text. Vv. 24-42 may be a late, anti-Samaritan polemical text, (Knoppers 2013, pp. 61-62; Kartveit 2014b). 
population is later than Josephus. What is evidently the idea of Josephus is that the Samaritans were opportunistic.

A second story on the background of the Samaritans is found in chapter 11 of the Antiquities:

Now the elders of the Hierosolymites, bitterly complaining about the fact that the brother of Jaddus the high priest, while married to a foreigner, was sharing the high priestly office, were agitating against him, for they thought that the marriage of this one [Manasses] would become a gangway for those who would wish to transgress the law concerning cohabitation with women, and that this would be for them [the Hierosolymites] the beginning of fellowship with foreigners ... . They, therefore, kept urging Manasses to be separated from [his] wife- or not to approach the sacrificial altar (Ant. 11.306-308; Spilsbury and Seeman 2017).

When Sanaballet promised not only to preserve the priesthood [for him], but also to procure [for him] the high priestly power and honor and to appoint [him] governor of all the places over which he himself was ruling - on condition that he be willing to live with his daughter-and saying that [he] would build a sanctuary that would be like the one in Hierosolyma on Mount Garizein, which is the highest of the mountains throughout Samaria, and as he promised that he would do these things with the consent of Darius the king, Manasses was elated by [these] promises and remained with Sanaballet, supposing that he would acquire the high priesthood given by Darius; for Sanaballet happened to be old by now (Ant. 11.310-311; Spilsbury and Seeman 2017).

Josephus describes the father-in-law of Manasses, Sanballat, as a Kuthean (Ant. 11.302), like the Samaritans. He intended to ask Darius for permission to build the temple when the conflict with Alexander had been fought to the end, but, contrary to expectations, Darius lost the battle at Issus, and Sanballat approached the Macedonian victor instead. Alexander's consent to build a temple in Samaria changed the situation fundamentally, resulting in a new cult center in the region. This encounter between the Samarian governor Sanballat and Alexander the Great took place during Alexander's siege of Tyre in 332 BCE. Providing one combines the two stories presented by Josephus, a double origin of the Samaritans emerges: one from Kutha, one from Jerusalem. Supposedly, the people brought in from Kutha over time intermarried with the alleged migrants from Jerusalem; and it would be logical to draw the conclusion that a mixed population was the result.

While Josephus builds his depiction of the origin of the Samaritans on 2 Kings 17, he evidently constructs the narrative of the origin of their temple on Neh 13:28-30a: "And one of the sons of Jehoiada, son of the high priest Eliashib, was the son-in-law of Sanballat the Horonite; I chased him away from me. Remember them, $\mathrm{O}$ my God, because they have defiled the priesthood, the covenant of the priests and the Levites. Thus I cleansed them from everything foreign" (NRSV). The major problem with the relationship between Neh 13:28-30a and Ant. 11.310-311 is that the expulsion of the priest from Jerusalem takes place in different centuries; according to the book of Nehemiah it was in the fifth century while, according to Josephus, it was in the fourth century. Different solutions to this conundrum have been suggested by scholars: that there were two expulsions; that Nehemiah is correct; that Josephus is correct; that both are correct, but in different ways (Dexinger 1992, pp. 105-27; Kartveit 2009, pp. 71-108; Pummer 2009, pp. 67-80, 103-52; 2016, pp. 54-66).

Josephus has a wide circle of followers over two millennia in his depiction of the origin of the Samaritans (see below).

\section{Did the Samaritans Come from the City of Samaria?}

The Samaritan model of their origin (They are the original Israel) and the model presented by Josephus (They descend from deportees and defectors from Jerusalem) have played a large role in scholarship. A different approach has been taken by G. Ernest Wright, who uses information in another group of sources. First, Eusebius in his Chronicle provides this story:

Alexander besieged Tyre and occupied Judah; glorified by the Jews, he sacrificed to God and honored the High Priest. He set Andromachus as the procurator of the land, whom the inhabitants of the city of the Samaritans killed; Alexander punished them when he had returned from Egypt, and, 
having occupied the city, he settled Macedonians to live there. (Eusebius, Chronicle, 112th Olympiad; Karst 1911)

Secondly, Curtius Rufus writes in his biography of Alexander (IV, 8, 9-11):

The sorrow was made greater by the news of the death of Andromachus, to whom he (scil. Alexander) had given the charge of Syria; the Samaritans had burned him alive. To avenge his murder, he hastened to the spot with all possible speed, and on his arrival those who had been guilty of such a great crime were delivered to him. Then he put Menon in place of Andromachus and executed those who had slain his general. (Rolfe 1946)

Thirdly, Syncellus tells that "He (scil. Alexander) appointed Andromachos to oversee the affairs of Judaea and the other areas. Because the inhabitants of Samaria killed him, they paid the penalty when Alexander returned from Egypt. He captured the city of Samaria and settled Macedonians there" (Adler and Tuffin 2002), and Hieronymus has a similar report on the resettlement of Samaria (Fotheringham 1905). Syncellus collects material from many sources for his history, so he only can claim authority insofar as his sources are reliable.

The time of this shift to a Macedonian population (often referred to as "Hellenization") of the city of Samaria is 332-331 BCE, and the city involved is supposedly Samaria (later called Sebaste). Taking the context of events taking place in 296-295 BCE, Eusebius mentions that Alexander's general Perdiccas, and not Alexander, re-settled the city of Samaria. The killing of Andromachus and the shift to a Macedonian populace may, therefore, have been two different events (Kippenberg 1971, p. 46); but the sources agree that the "Hellenization" of Samaria took place in the late fourth or the beginning of the third centuries, and Curtius Rufus describes Alexander's reorganizing of the government of the city.

This re-foundation with a new population is confirmed indirectly by a find in Wadi Daliyeh (grid references 189.155), $40 \mathrm{~km}$ south-east of the city of Samaria. The remains of 200-300 persons were found in a cave in 1962, having been suffocated there in the last third of the fourth century BCE. They had brought with them bullae and documents with slave contracts in Aramaic, written in the city of Samaria in the previous decades. It seems that this upper-class contingent fled into the desert when the re-settlement with Macedonians took place, where they were trapped in a cave and suffocated by a fire lit at the entrance to the cave. The onomasticon of these documents is mainly Yahwistic, testifying to the Yahwistic profile of the cult in the city of Samaria (Dušek 2007, pp. 486-89).

G. Ernest Wright combines the settlement of the city of Samaria by Macedonians with archaeological results from Shechem (Tell Balata, not to be confused with Nablus, which was founded in the late first century CE in Mabartha). Shechem lay desolate from early in the fifth century BCE to the latter part of the fourth, and its re-population calls for an explanation. G. Ernest Wright excavated Shechem, and suggested:

It seems to us that the simplest view is provided by taking the Eusebius-Syncellus statement at face value about Alexander's destruction of Samaria and turning it over to Macedonians. This would mean that the Samaritans were forced to establish a new capital, and the logical place was old Shechem, at a time when Samaritans were so anxious to maintain their claims over against the Jews and Jerusalem (Wright 1962, p. 365).

This is a possibility, difficult to prove, but Shechem was re-established in this period, and its history gave it an important status.

This theory should be seen together with Josephus's explanation for the construction of the temple in Antiquities chapter 11 (cf. the quotation above): he has Sanballat instituted as satrap (in fact, he was a governor) of Samaria by Dareios III, and the daughter of this Sanballat married into the family of high priests of Jerusalem. According to Nehemiah, this was a defilement of the priesthood; according to Josephus, this constituted a danger of accepting priests who transgressed the laws for marriage and had intercourse with foreigners. To keep his daughter married, Sanballat defected from the Persians, approached Alexander, whose authorization he sought, promising to the Macedonian king that a second temple would split the power $(\delta \dot{v} v \alpha \mu \iota \varsigma)$ of the Jews, thus facilitating Macedonian rule. 
Josephus generally describes the Samaritans as opportunistic and does not mention the "Hellenization" of Samaria; it is difficult to assess the motives of Sanballat. The argument for a new sanctuary in the north fits with Josephus' portrayal of the Samaritans. Although Josephus does not mention any events at this time in the city of Samaria—and he may not have been aware of the "Hellenization"—-there is no contradiction between the information in Eusebius, Curtius Rufus and Syncellus on the one hand, and Josephus' account on the other. The other sources may describe the historical background to the revival of settlement in Shechem and the temple building on Mount Gerizim, and Josephus chose to see it from a different angle. His agenda was to discredit the temple on Mount Gerizim, and this he obtained by using the sources he had at his disposal.

I find Wright's theory interesting and it can be combined with information in Josephus. The northerners of the fifth and fourth centuries worshiped Yahweh in Samaria, and the shift in population to a Macedonian settlement of the city of Samaria in 332-331 BCE and the concomitant change in religious adherence could potentially have strengthened the religious position of Jerusalem as a Yahweh center. However, if Josephus is right about the dating of the temple on Mount Gerizim, then this new center for worship presented a danger to Jerusalem: Samaria had become pagan, but Mount Gerizim carried on the Yahweh-worship in the north. A possible strengthening of Jerusalem would not take place, since there continued to be a Yahweh center in the north, competing with Jerusalem.

\section{Qumran: A New Direction in the Search for the Origin}

The theories mentioned above work with material known for a long time, and with results from the twentieth century excavations of Shechem. Accompanying the discovery of the manuscripts in Qumran, scholars suddenly had new sources in their hands, which changed the course of investigation. The manuscripts came under professional study in 1947 and new texts turned up until 1955 from several locations, but it was only in an article in 1955 that scholars dealing with Samaritans saw their value in connection with the Samaritans.

The 1955 article by Patrick W. Skehan presented what he called "Exodus in the Samaritan Recension from Qumran". This article announced that among the Qumran texts there was a scroll of Exodus with features that were previously only known from the SP: 4QpaleoExod ${ }^{\mathrm{m}}$. One can perceive the author's joy of discovery in the presentation of the scroll:

The Exodus scroll ... has been judged of sufficient interest to make a preliminary notice desirable in advance of the full edition of the biblical texts from Cave 4 at Khirbet Qumran ... The recension in question is the "Samaritan" recension, with all the essential characteristics of that fuller text, including its repetitious manner of recounting the plague episodes, its borrowings from Deuteronomy and its transpositions; this is true at almost every point where the extant fragments make verification possible. (Skehan 1955, p. 182)

The significance of this discovery was enhanced by these observations: "The script cannot by any stretch of the imagination be called Samaritan ... Neither is the orthography Samaritan." Skehan's "surprise" was therefore that "the Samaritan recension ... is shown by this scroll to have been preserved with a measure of fidelity ... that compares not unfavourably with the fidelity of transmission of MT itself ... " Taking the assumption that the text in significant respects was the "Samaritan recension", he concluded that this recension had been preserved well over the ages. Furthermore, as he surmised that the recension was Samaritan, but the script and the orthography were not, he cautiously concluded that a suspended judgement was called for on the question of the scroll's Samaritan character (Skehan 1955, pp. 182-83).

Skehan, in this article, briefly introduced the scroll and then presented a photograph of one column containing Exod 32:10-30 (later known as col. XXXVIII) with Hebrew transcription and comments. Skehan's overall evaluation of the scroll is twofold:

By way of conclusion, the writer wishes to underline the judgment implicit in what has been said above: that this new evidence for the antiquity and for the constancy of transmission of the Samaritan recension of Exodus does not alter the internal evidence for the secondary character of much that 
is proper to that recension, and that the general appraisal of the recension itself remains in outline substantially what it has been since the time of Gesenius. (Skehan 1955, p. 183)

Skehan referred to Wilhelm Gesenius' study (Gesenius 1815) but failed to see the significance of the fact that the "essential characteristics" of the "Samaritan recension" had been found at Qumran.

Maurice Baillet, in 1988, presented a study of the Samaritan Pentateuch (SP) in the Hebrew, Greek, Aramaic, and Arabic versions (Baillet 1988, pp. 531-44). Regarding the Hebrew SP he concluded that: (1) the Samaritan script descends from the pre-exilic Palaeo-Hebrew script; (2) many SP scribal details are attested at Qumran; (3) the Samaritan pronunciation is partly a vestige of the ancient Palestinian pronunciation; (4) the Samaritan recension is the daughter of a pre-masoretic recension; (5) the decisive period for the fixation of the Samaritan text and letters is between the end of the 1st and the 3rd century CE. During this period the addition of the tenth commandment also took place.

More than any other scholar, Emanuel Tov has worked with the Dead Sea Scrolls (DSS). He coined the term "pre-Samaritan" texts among the DSS and has led the discussion on this topic. Recently he has expressed his views on this question carefully:

The most characteristic readings of the [SP]-group were created by substantial editorial changes inserted in the earlier text ... These changes involve additions (duplications) of other Torah verses (with changes in names and verbal forms) and a few rearrangements but no omissions, following a strong inclination in [SP] not to alter the divine word. The changes should be considered editorial rather than harmonizing ... characteristic of the [SP]-group only ... Ultimately, the changes reflect theological concerns. (Tov 2012, p. 80)

One notes his assessment: the major expansions reveal an editorial activity rather than being harmonizations. Generally, the DSS are not Samaritan (Crawford 2019, pp. 295-96), but there are traits in some of them that are reminiscent of the Samaritan Pentateuch.

The whole pre-Samaritan group among the DSS is a text type that can be called harmonistic and with content editing, but inside this group there is one manuscript that most closely resembles the SP: 4 QpaleoExod ${ }^{\mathrm{m}}$. It has no expansions with non-Biblical text of the type found in $4 \mathrm{QRP}$, only expansions copied from the Pentateuch, of the type found in SP. This is not to say that 4 QpaleoExod ${ }^{\mathrm{m}}$ is a Samaritan text; concerning this question, the first judgment by Skehan was unfounded. This manuscript probably did not contain the Samaritan tenth commandment because there is no room for it in column XXI and, therefore, it was no Samaritan manuscript (Sanderson 1986, p. 317).

It had, however, room for the expansion that mentions a future prophet like Moses, an expansion in Exod 20:21, extant in the SP. It consists of text from Deut 5:28-29; 18:18-22; 5:30-31. An overall assessment of the scroll in relation to SP allows for the assumption that 4QpaleoExod ${ }^{\mathrm{m}}$ was the ancestor of the SP, in my opinion, and this assumption will be substantiated in other publications. We find an important background for the forming of the Samaritan movement in the DSS-a possibility hitherto not considered enough in modern scholarship-if this is a correct assumption.

When the commandment to build an altar at Mount Gerizim was added, we can speak of a Samaritan text. The system of quoting existing Pentateuchal text for creating an expansion also was used in the case of this commandment, and it is probable that it was created at a time when content editing is visible in the DSS, which means sometime around the turn of the eras. Additional to the tenth commandment, the SP shows some other significant readings, for example the construction of the altar on Mount Gerizim instead of on Mount Ebal, Deut 27:4, the special form of the altar law in Exod 20:24, and the past tense of the phrase "the place that the Lord your God has chosen," found 21 times in Deuteronomy. Such readings may be old, and it makes sense to locate them in a time and age when the Samaritan features of the SP emerged. Adrian Schenker has suggested that the reading "the place that the Lord your God has chosen" is original (Schenker 2008), and Stefan Schorch and Jan Dušek have accepted this view (Schorch 2011, p. 32; Dušek 2012, p. 90), but Sidnie White Crawford and Raik Heck1 have contested this dating (Crawford 2017, pp. 102-3; Heckl 2016b), and a Samaritan provenance seems most probable for the reading "has chosen". Due to the character of the content editing that shaped the Samaritan tenth commandment and the similar nature of the earlier content editing of 
the pre-Samaritan texts, it is tempting to assume also a similarity in milieu or even scribal schools. The oldest pre-Samaritan text is from $250 \mathrm{BCE}$, and the use of the old script is well documented in the DSS. It is used particularly in manuscripts dealing with Moses.

The pre-Samaritan texts prove that the version of the Pentateuch used by the Samaritans had its roots in a Jewish collection of Biblical texts. Concerning this, the Samaritans constitute a branch of Judaism, and one of their roots was in Judaism BCE. An Editio Maior of The Samaritan Pentateuch is now published by Stefan Schorch, and the volume with Leviticus has appeared (Schorch 2018).

\section{The Excavations on Mount Gerizim and the Discovery of Samaritan Inscriptions}

Until recently, scholars dated the construction of the cult site on Mount Gerizim on the basis of Josephus' account: to the beginning of the Hellenistic age. We now have new material relevant for this question in the form of results from the excavations on the summit of Mount Gerizim. These went on for more than 20 years from 1982, done by Yitzhak Magen and his team. The results have added important evidence for the origins of the Samaritans. Based on coins, pottery, and architecture, the excavator in 2004 assessed the finds as follows:

The sacred precinct, centered around the temple, was built on the highest point on the mountain, overlooking the central crossroads of Samaria, Mt. Ebal, Shechem (Tell Balatah) and, to the east, the fertile Sukkar and Dajjan valleys. The excavations revealed two main construction phases: the precinct and the temple were first built in the fifth century BCE, during the Persian period, and survived until the end of Ptolemaic rule in the Land of Israel; the Seleucid conquest was followed by the rebuilding of the sacred precinct and the temple, in the early second century BCE. (Magen et al. 2004, p. 3).

Unfortunately, Magen did not find any traces of the temple or a similar structure dating to any of the two phases he describes but adduces the hundreds of thousands of burnt animal bones which were found inside thick layers of ash as circumstantial evidence for an altar or even a temple. Most of the bones are from goats and sheep, but cattle and pigeons also are represented. The excavators evaluate this as evidence for the worship of the God of Israel, as the bones come from animals that were deemed fit for sacrifice in Leviticus. The bones are dated by the Carbon 14-method to the Persian and Hellenistic times. Similarly, pottery and coins were found which derived from the same times. The earliest coin dates from $480 \mathrm{BCE}$, and 68 coins belong to the fifth and fourth centuries BCE (preceding the arrival of Alexander the Great in the Land of Israel). The latest coins are dated to the last part of the second century BCE, and this is taken as an indication of John Hyrcanus' destruction of the site, as described by Josephus (War 1.62-63; Ant. 13.245-256).

During the excavations, 395 inscriptions and fragments of inscriptions in Hebrew and Aramaic were found. Additionally, a number of inscriptions in Greek were secured. No images were uncovered. The Greek inscriptions have not been made available yet, but the Hebrew and Aramaic inscriptions were published in (Magen et al. 2004) ${ }^{2}$. The publishers date the inscriptions to the Persian and Hellenistic periods, and Jan Dušek narrows the time frame down to the first part of the second century BCE (Dušek 2012). Such a precise dating might be open to discussion, but scholars agree that the inscriptions come from the time of the city on Mount Gerizim. They were not found in situ, and we lack precise information on their provenance inside the city. Most of them are fragmentary, but numbers 17, 20, and 147 (text damaged at two places) are intact. These three complete inscriptions are all written in Aramaic; apart from that, they are all different (Magen et al. 2004).

2 The study of Anne Katrine de Hemmer Gudme of the Gerzim inscriptions is extensive (De Hemmer Gudme 2013), but she pays only scant attention to the phrase "in this place", which is the novelty in the Gerizim inscriptions, and does not occur in her comparative material. 
Inscription number 17 is written in a monumental Aramaic script and is found on a large stone, $103 \times 37 \times 31 \mathrm{~cm}$.

זי הקרבת מרימ על נפשה ועל 1

2 בניה 2

1 This is [the stone] that Miriam dedicated for her soul and for

2 her children/sons.

Inscription number 20 uses monumental Aramaic script and was inscribed on a large stone, broken into two parts, together measuring $110 \times 34 \times 22 \mathrm{~cm}$.

זי הקרב ח[צל]א בר זבדי ויהונתנ 1

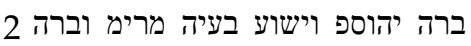

1. This is [the stone] that 'A[șl]ah, son of Zabdi, and Yehonatan,

2 his son, Yehosef and Yeshua', Ba'yah, Miriam, and her son dedicated.

Inscription number 147 is longer, incised on a large, intact stone of $202 \times 36.5 \times 55 \mathrm{~cm}$, and it stretches over the full length of the stone. Its script is cursive:

די הקרב דליה בר שמעון עלוהי ועל בנוהי אבנא ד[ה ל]דכרנ טב קדמ אלהא באתרא דנה 1

1 This is [the stone] that Delayah, son of Shim'on, dedicated for himself and his children/sons, [this] ston[e for] good remembrance before God in this place.

When we look at the inscriptions at large, we find that their onomasticon is almost completely Yahwistic. Additionally, "YHWH" is found in inscription number 383 (a fragment). The places named (or restored) are Shamrayin (numbers 14 and 15), Shechem (numbers 12, 36, and 39), the village of Haggai (number 3), Awarta (number 8), Yokmeam (number 7), The Good Mountain (number 11), and Mabartha (number 76). Most of these places are found on or around Mount Gerizim. Further, Mount Gerizim had a "house of sacrifice" (בית דבחא, number 199), and a "sanctuary," (מקדש, number 150), and the animal bones found at the site provide ample evidence of sacrifices.

Many of the elements in these inscriptions are common to the period and can be found in other sacred sites in the Levant. But number 147 uses the phrase באתרא דנה, "in this place." This phrase is found or reconstructed in 14 or 15 inscriptions. It reminds us of the 21 cases in Deuteronomy with the 'centralization command' (see above), many of which also have the phrase "before God/the Lord", just like many of the Gerizim inscriptions. The Gerizim inscriptions with these phrases, therefore, seem to echo Deuteronomy. The editors are probably right in stating that "this phrase has a different task: to emphasize the sanctity of Mt. Gerizim as opposed to that of Jerusalem." (Magen et al. 2004, p. 19). We may compare the phrases "this mountain" versus Jerusalem, and "the place where one

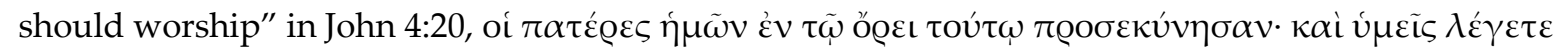

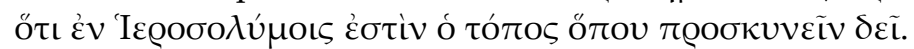

Taken from the same period come two inscriptions on the island of Delos in the Aegean Sea, found in 1979 (IJudOr I Ach 66 and 67) (Ameling et al. 2004). They were commissioned by "Israelites" who send their temple tax to "Argarizein" (Mount Gerizim). The last editors date these texts to 150-50 BCE, but a date in the first half of the second century also is possible. IJudOr I Ach 67 starts in this way:

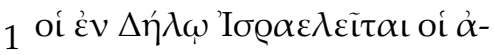

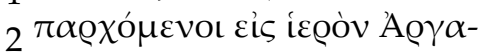

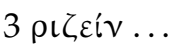

1 The Israelites in Delos who se-

2 nd their temple tax to sacred Arga-

3 rizein ...

IJudOr I Ach 66 starts thus:

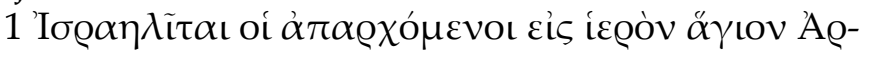

$2 \gamma \alpha \rho \iota \zeta \varepsilon i v \ldots$ 
1 Israelites who send their temple tax to sacred, holy Ar-

2 garizein.

The people behind these inscriptions call themselves "Israelites" and this is the oldest attestation of the later so well-known self-designation of the Samaritans. The next information of some consequence here is the name of the mountain, Argarizein, a contraction and transliteration of the Hebrew name "Mount Gerizim." This is an old Samaritan designation of the mountain, developed into a name, and by some ancient authors used in a derogatory sense. We see that this Delos community used a correct Samaritan name for the mountain, and the oldest known self-designation for themselves. The participle, $\dot{\alpha} \pi \alpha \rho \chi \emptyset ́ \mu \varepsilon v o l$, from $\dot{\alpha} \pi \dot{\alpha} \rho \chi 0 \mu \alpha \iota$, "to make (a first) offering," could refer to the temple tax, Exod 30:11-16, paid by Jews to the temple in Jerusalem and, accordingly, by Samaritans to Mount Gerizim, possibly at a time when the temple there was operating. These inscriptions were aimed to honour beneficiaries who had contributed to the building of Samaritan synagogues. During that time, there was a Jewish presence on the island of Delos, and Jewish synagogues as well.

The inscriptions from Mount Gerizim and from Delos witness to a developed self-consciousness in the early second Century BCE, rejecting Jerusalem as a place of worship (Kartveit 2014a). Excavations and inscriptions show a functioning community centred on Mount Gerizim in the second century BCE, with roots in earlier periods. This is now generally acknowledged by scholars (Magen et al. 2004; Pummer 2016; Knoppers 2013).

\section{The Origin of the Samaritans-Then and Now}

Reviewing the material presented in this article, it is probably correct to state that the oldest theory of the origin of the Samaritans is found in 2 Kings 17:24-41. It is a polemical text from the last centuries BCE against the Samaritans, stating that they came from the five peoples deported into Samaria by the Assyrians in the eighth century BCE. Josephus in the first century CE repeats and enlarges this biblical statement in book 9 of his Antiquities. Found in book 11 he adds the story of the erection of the temple on Mount Gerizim. The church fathers generally follow Josephus (Pummer 2002). Modern scholars with theories of this type are listed in (Kartveit 2009, pp. 49-58).

During the late Middle Age, the Samaritans produced their theory of their origin in the chronicles of the 14. century CE, repeated in later chronicles. As mentioned, Gaster and Macdonald follow them.

Modern study of the question started with James Alan Montgomery's book from 1906. He did not adopt the Samaritan version, but still suggested that the roots of Samaritanism must be sought in the faithful remnant that remained in Samaria after the Assyrian conquest. He thus opened the idea that there is a continuation from early Israel in the north to the Samaritans. This lead has been followed by later scholars (Nodet 1997; Hjelm 2000; Diebner 2011). The notion that the Samaritans are Israelites, descendants of Old Israel, is one of the main theories until today. One recent example: Lee Martin McDonald, in his 2017 book, devotes a paragraph to "The Samaritan Bible", found in Chapter 7 dealing with "Scripture among Essenes, Sadducees, Pharisees, and Samaritans." McDonald opens this paragraph by stating that "Many of the Jews who survived the 721 BCE Assyrian invasion of the northern tribes of Israel with the capture of Samaria, its capital, subsequently intermarried with the Assyrians and became known as 'Samaritans.' The Jews to the south tended to view them as despised 'half-breeds' and rejected their participation in the life of the nation and its temple cultus." (McDonald 2017, p. 264). The use of "Jews" for the Israelites of the eighth century BCE is not common today, and the theory of the mixed origin of the Samaritans owes its main impetus to the version presented by Josephus, even though he portrays them rather as foreigners. Similar statements of a mixed population with syncretism can be found in Freudenthal (1874, p. 96), Di Lella and Skehan (1987, p. 558), and The Hodder and Stoughton Illustrated Bible Dictionary (Lockyer 1986).

Modern biblical scholars often have built upon the book of Nehemiah, assuming that it reports from 445 BCE, and believed that the rejected people of the land were the Samaritans (Mor 1989). They had not been exiled, and did not qualify for membership in the Jerusalem community. 
William Foxwell Albright suggested in 1940 that the period after the destruction of the temple was decisive for the Samaritan group:

If we compare the oldest lapidary examples of Samaritan writing with the coins of the Hasmoneans, dated between 135 and 37 B.C., a relatively late date for the origin of the Samaritan script as such seems highly probable. Moreover, since Shechem and Samaria were conquered by the Jews between 128 and 110 B.C. and were lost to the Romans in 63 B.C., it would be only natural to date the final schism between the sects somewhere in the early first century B.C. It was presumably then or somewhat later that the entire Samaritan Pentateuch was re-transcribed into the archaizing "Samaritan" script, which symbolized the refusal of the Samaritans to follow the "modernists" of Jerusalem. (Albright 1940, p. 345, n. 12)

The discovery of the Dead Sea Scrolls, archaeological excavations on Mount Gerizim with the inscriptions found there, and the find of the Delos inscriptions have changed much of the basis for Albright's ideas. The SP was 're-transcribed' into an archaizing script in the sense that the later Samaritan script probably was developed from one of the scripts used in the DSS and in the Mount Gerizim inscriptions. Albright uses the term "sect", so often found in earlier and later scholarship, but eschewed by most scholars today. Moreover, a lack of relevant material from the first century BCE makes it difficult to prove or disprove the hypothesis. Against the backdrop of what we know of the cult on Mount Gerizim before the temple, its city, and Shechem were destroyed, the task is to assess the effects of such dramatic change: did it lead to a period of low activity, or did it boost the group's activity? However, Albright's statement has been quoted and developed by Frank Moore Cross, Jr. (Cross 1966) and, though the parlance has changed, it still inspires scholars to think in similar terms. Based on all the material now available, scholars still may consider the destruction of the temple on Mount Gerizim a "momentous event" (Pummer 2002, p. 2) that shaped the course of history (Knoppers 2013, p. 216; Pummer 2016, pp. 24-25).

James Alan Montgomery used the word "sect" (Montgomery 1906), but an important move away from this usage is the book by Coggins (Coggins 1975), in which he advocates a model of estrangement rather than a rupture.

New publications in Biblical studies take the Samaritan question more seriously than what was the case earlier. The 2007 publication, The Pentateuch as Torah, edited by Gary Knoppers and Bernard Levinson (Knoppers and Levinson 2007), contains several articles with a new discussion of the situation (especially the contribution by Christophe Nihan, pp. 187-224). Raik Heckl and Benedikt Hensel, in 2016, each published their own monograph on the Judea/Yehud-Samaria questions (Heckl 2016a; Hensel 2016), where they, from different viewpoints, opt for continuous religious development and contacts between Jerusalem and Samaria. During the congress of the International Organization of the Old Testament in Stellenbosch 2016, two sessions dealt with the Samaritans from the angle of Hebrew Bible and Samaritan material. The presentations at the conference, plus additional chapters, are published (Kartveit and Knoppers 2018). A combination of continuity and estrangement dominate the scholarly field on this question today. This development seems to continue.

The material reviewed here indicates that a theory on the origin of the Samaritans must reckon with an origin of their Pentateuch inside a Jewish milieu of the last three BCE-centuries, with a city and a cult site on Mount Gerizim which flourished in the early second century BCE, and had a history before that time, and in that period the Samaritans had a developed self-consciousness. The initial construction on the mountain is still a matter of dispute.

When and how did the Samaritans emerge? The answers to these questions depend on which parts of the material one would prioritize. They were there as a group with some history and standing at the time of the New Testament and Josephus. The formative period for them seems to have been the preceding centuries.

Their number and status today may be modest: around 800 people living on Mount Gerizim and in $\mathrm{H}_{\mathrm{S}}$ lon near Tel Aviv. However, their name is widely known—even among people who have no idea of Samaritans at the time of the Bible or today. Their origin is still a fascinating object for research. 
Funding: This research received no external funding.

Conflicts of Interest: The author declares no conflict of interest.

\section{References}

Adler, William, and Paul Tuffin. 2002. The Chronography of George Synkellos: A Byzantine Chronicle of Universal History from the Creation. Translated by William Adler, and Paul Tuffin. Oxford: Oxford University Press.

Albright, William Foxwell. 1940. From the Stone Age to Christianity. Baltimore: Johns Hopkins Press.

Ameling, Walter, David Noy, Alexander Panayotov, and Hanswulf Bloedhorn. 2004. Inscriptiones Judaicae Orientis. Texts and Studies in Ancient Judaism. Tübingen: Mohr Siebeck, vol. 3.

Baillet, Maurice. 1988. Les divers états du Pentateuque samaritain. Revue de Qumran 13: 531-45.

Begg, Christopher, and Paul Spilsbury. 2005. Flavius Josephus: Judean Antiquities Books 8-10. Translation and Commentary. Leiden: Brill.

Coggins, Richard J. 1975. Samaritans and Jews: The Origin of Samaritanism Reconsidered. Oxford: Blackwell.

Crawford, Sidnie White. 2017. 2.2.4.5. Deuteronomy. In Textual History of the Bible. Vol. 1B Pentateuch. Former and Latter Prophets. Edited by Armin Lange and Emanuel Tov. Leiden and Boston: Brill, pp. 101-5.

Crawford, Sidnie White. 2019. Scribes and Scrolls at Qumran. Grand Rapids: Eerdmans.

Cross, Frank Moore, Jr. 1966. Aspects of Samaritan and Jewish History in Late Persian and Hellenistic Times. HTR 59: 201-11. [CrossRef]

De Hemmer Gudme, Anne Katrine. 2013. Before the God in this Place for Good Remembrance: A Comparative Analysis of the Aramaic Votive Inscriptions from Mount Gerizim. BZAW 441. Berlin: de Gruyter.

Dexinger, Ferdinand. 1992. Der Ursprung der Samaritaner im Spiegel der frühen Quellen. In Die Samaritaner. Edited by Ferdinand Dexinger and Reinhard Pummer. Darmstadt: Wissenschaftliche Buchgesellschaft, pp. 62-140.

Di Lella, Alexander A., and Patrick William Skehan. 1987. The Wisdom of Ben Sira: A New Translation with Notes, Introduction and Commentary. New York: Doubleday.

Diebner, Bernd Jørg. 2011. Seit wann gibt es "jenes Israel"? Gesammelte Studien zum TNK und zum antiken Judentum: Bernd J. Diebner zum 70. Geburtstag. Beiträge zum Verstehen der Bibel. Münster and Westf: LIT.

Dušek, Jan. 2007. Les Manuscrits Araméens du Wadi Daliyeh et la Samarie Vers 450-332 av. J.-C. Culture and History of the Ancient Near East. Leiden: Brill.

Dušek, Jan. 2012. Aramaic and Hebrew Inscriptions from Mt. Gerizim and Samaria between Antiochus III and Antiochus IV Epiphanes. Culture and History of the Ancient near East. Leiden and Boston: Brill.

Fotheringham, John Knight. 1905. The Bodleian Manuscript of Jerome's Version of the Chronicles of Eusebius. Oxford: Clarendon Press.

Freudenthal, Jacob. 1874. Hellenistische Studien: Heft I. Alexander Polyhistor und die von ihm erhaltenen Reste jüdischer und samaritanischer Geschichtswerke. In Jahresbericht des jüdisch-theologischen Seminars "Fränkelscher Stiftung". Breslau: Grass.

Gaster, Moses. 1925. The Samaritans: Their History, Doctrines and Literature. London: Oxford University Press.

Gesenius, Wilhelm. 1815. De Pentateuchi Samaritani Origine, Indole et Auctoritate: Commentatio Philologico-Critica. Halae: Rengerianae.

Heckl, Raik. 2016a. Neuanfang und Kontinuität in Jerusalem. Forschungen zum Alten Testament 104. Tübingen: Mohr Siebeck.

Heckl, Raik. 2016b. Überlegungen zu Form und Funktion der Zentralisationsformel im Konzept des samaritanischen Pentateuch, zugleich ein Plädoyer für die Ursprünglichkeit der masoretischen Lesart. Zeitschrift für Altorentalische und Biblische Rechtsgeschichte 23: 191-208.

Hensel, Benedikt. 2016. Juda und Samaria. Zum Verhältnis Zweier Nach-Exilischer Jahwismen. Forschungen zum Alten Testament 110. Tübingen: Mohr Siebeck.

Lockyer, Herbert. 1986. The Hodder and Stoughton Illustrated Bible Dictionary. Nashville: Nelson.

Hjelm, Ingrid. 2000. The Samaritans and Early Judaism: A Literary Analysis. JSOT Sup. Sheffield: Sheffield Academic Press.

Karst, Josef. 1911. Die Chronik aus dem Armenischen übersetzt. Die Griechischen Christlichen Schriftsteller der Ersten drei Jahrhunderte. Leipzig: J.C. Hinrichs.

Kartveit, Magnar. 2009. The origin of the Samaritans. Supplements to Vetus Testamentum. Leiden and Boston: Brill. 
Kartveit, Magnar. 2014a. Samaritan Self-Consciousness in the First Half of the Second Century B.C.E. in Light of the Inscriptions from Mount Gerizim and Delos. JSJ 24: 449-70. [CrossRef]

Kartveit, Magnar. 2014b. The Date of II Reg 1724-41. ZAW 126: 31-44.

Kartveit, Magnar, and Gary Knoppers, eds. 2018. The Bible, Qumran, and the Samaritans. SJ 104/StSam 10. Berlin: de Gruyter.

Kippenberg, Hans G. 1971. Garizim und Synagoge: Traditionsgeschichtiche Untersuchungen zur samaritanischen Religion der aramäischen Periode. Religionsgeschichtliche Versuche und Vorarbeiten. Berlin and New York: De Gruyter.

Knoppers, Gary N. 2013. Jews and Samaritans: The Origins and History of Their Early Relations. Oxford: Oxford University Press.

Knoppers, Gary, and Bernard Levinson, eds. 2007. The Pentateuch as Torah: New Models for Understanding Its Promulgation and Acceptance. Winona Lake: Eisenbrauns.

Macdonald, John. 1964. The Theology of the Samaritans. New Testament Library. London: SCM Press.

Magen, Yitzhak, Haggai Misgav, and Levana Tsfania. 2004. Mount Gerizim Excavations: Volume I: The Aramaic, Hebrew and Samaritan Inscriptions. Judea and Samaria Publications. Jerusalem: Staff Officer of Archaeology-Civil Administration of Judea and Samaria, Israel Antiquities Authority.

McDonald, Lee Martin. 2017. The Formation of the Biblical Canon. London and New York: Bloomsbury T \& T Clark, vol. I.

Montgomery, James Alan. 1906. The Samaritans, the Earliest Jewish Sect: Their History, Theology and Literature. The Bohlen Lectures 1906. New York: Ktav Publishing House.

Mor, Menahem. 1989. I. Samaritan History: 1. The Persian, Hellenistic and Hasmonean Period. In The Samaritans. Edited by Alan D. Crown. Tübingen: Mohr Siebeck, pp. 1-18.

Nodet, Etienne. 1997. A Search for the Origins of Judaism: From Joshua to the Mishnah. JSOT Sup. Sheffield: Sheffield Academic Press.

Pummer, Reinhard. 1976. The Present State of Samaritan Studies: I. JSS 21: 39-61. [CrossRef]

Pummer, Reinhard. 1977. The Present State of Samaritan Studies: II. JSS 22: 27-47. [CrossRef]

Pummer, Reinhard. 1992. Einführung in den Stand der Samaritanerforschung. In Die Samaritaner. Edited by Ferdinand Dexinger und Reinhard Pummer. Darmstadt: Wissenschaftliche Buchgesellschaft, pp. 1-66.

Pummer, Reinhard. 2002. Early Christian Authors on Samaritans and Samaritanism: Texts, Translations, and Commentary. Texts and studies in Ancient Judaism. Tübingen: Mohr Siebeck.

Pummer, Reinhard. 2009. The Samaritans in Flavius Josephus. Texts and Studies in Ancient Judaism. Tübingen: Mohr Siebeck.

Pummer, Reinhard. 2016. The Samaritans: A Profile. Grand Rapids: William B. Eerdmans Publishing Company.

Purvis, James D. 1986. The Samaritans and Judaism. In Early Judaism and Its Modern Interpreters. Edited by Robert A. Kraft and George W. E. Nickelsburg. Atlanta: Scholars Press, pp. 81-98.

Rolfe, John Carew. 1946. Quintus Curtius Rufus: Historia Alexandri Magni Macedonis. Translated by John C. Rolfe, and Loeb Classical Library. Cambridge and London: Harvard University Press.

Sanderson, Judith E. 1986. An Exodus Scroll from Qumran: 4QpaleoExodm and the Samaritan Tradition. Harvard Semitic Studies. Atlanta: Scholars Press.

Schenker, Adrian. 2008. Le Seigneur choisira-t-il le lieu de son nom ou l'a-t-il choisi? L'apport de la Bible grecque ancienne à l'histoire du texte samaritain et massorétique. In Scripture in Transition: Essays on Septuagint, Hebrew Bible and Dead Sea Scrolls in Honour of Raja Sollamo. Edited by Anssi Voitila and Jutta Jokiranta. JsJSup 126. Leiden: Brill, pp. 339-52.

Schorch, Stefan. 2011. The Samaritan Version of Deuteronomy and the Origin of Deuteronomy. In Samaria, Samarians, Samaritans: Studies on Bible, History and Linguistics. Edited by Jószef Zsengellér. Studia Judaica 66, Studia Samaritana 6. Berlin: de Gruyter, pp. 23-37.

Schorch, Stefan. 2018. The Samaritan Pentateuch: A Critical Editio Maior. Leviticus. Berlin: de Gruyter, vol. 3.

Skehan, Patrick W. 1955. Exodus in the Samaritan recension from Qumran. Journal of Biblical Literature 74: 182-87. [CrossRef]

Spilsbury, Paul, and Chris Seeman. 2017. Judean Antiquities 11: Translation and Commentary. Flavius Josephus: Translation and Commentary. Leiden: Brill.

Stenhouse, Paul. 1985. The Kitāb al-tarīkh of Abu 'l-Fath. Translated by Paul Stenhouse. Studies in Judaica. Sydney: Mandelbaum Trust and University of Sydney. 
Tov, Emanuel. 2012. Textual Criticism of the Hebrew Bible, 3rd ed. Minneapolis: Fortress.

Wright, G. Ernest. 1962. The Samaritans at Shechem. HTR 55: 357-66. [CrossRef]

(C) 2019 by the author. Licensee MDPI, Basel, Switzerland. This article is an open access article distributed under the terms and conditions of the Creative Commons Attribution (CC BY) license (http://creativecommons.org/licenses/by/4.0/). 